\title{
純スズの動的再結晶
}

\author{
砂田俊秀什大塚正久* \\ 山縣 裕** 藤 原 雅 美*** \\ *芝浦工業大学工学部材料工学科 \\ **ヤマ八発動機株式会社研究開発センター \\ ***日本大学工学部総合教育学科
}

J. Japan Inst. Metals, Vol. 63, No. 4 (1999), pp. 467-473

\section{Dynamic Recrystallization of Pure Tin}

Toshihide Sunada*†, Masahisa Otsuka*, Hiroshi Yamagata** and Masami Fujiwara***

\author{
*Department of Material Science, Shibaura Institute of Technology, Tokyo 108-8548 \\ ${ }^{* *} R$ \& D Division, Yamaha Motor Co., Ltd., Iwata 438-8501 \\ ***Department of General Education, College of Engineering, Nihon University, Koriyama 963-1165
}

\begin{abstract}
Constant-compressive-load creep testing on polycrystalline (average grain size; $1.48 \mathrm{~mm}$ ) and [110] single crystalline Sn was carried out at 393.K. Rapid increases in the creep rate (strain burst) were observed for polycrystalline $\mathrm{Sn}$ under stresses ranging from 3.5 to $5.5 \mathrm{MPa}$. The strain burst was also observed for a single crystalline $\mathrm{Sn}$ at $5 \mathrm{MPa}$. Microstructural observations revealed that the newly recrystallized grains contain subgrains and that the strain burst is caused by dynamic recrystallization. A constant-compression-speed testing was also performed at a strain rate of $1.67 \times 10^{-3} \mathrm{~s}^{-1}$ and at $393 \mathrm{~K}$. The stress-strain curve showed a multipeak stress-strain curve which is typical of dynamic recrystallization.
\end{abstract}

(Received November 4, 1998, In Final Form January 11, 1999)

\begin{abstract}
Keywords: tin, creep testing, constant compression speed testing, microstructure, dynamic recrystallization, subgrain, grain boundary migration, grain boundary sliding, elevated temperature deformation
\end{abstract}

\section{I 。緒言}

スズは室温が， $0.6 T_{\mathrm{m}}\left(T_{\mathrm{m}}\right.$ は融点 $)$ に相当し，容易にクり ープ変形が起こる. 室温で安定な $\beta$ スズは体心正方構造を 取り，特徵的な変形機構を示すことから多くの研究がなされ ている。これらの研究の大部分は変形の活性化エネルギの測 定(1)-(6)などに主眼が置かれている. そして変形挙動の研究 から, 動的復旧の機構は, 動的回復によると考えられている.

引張試験は広範囲の試験条件で行われている(7). 変形後の 組織は引張軸方向に引き延ばされて，応力-歪曲線には定常 変形状態が現れる。クリープ曲線は正遷移型クリープ曲線が 報告されている。 しかし，ChuとLiの押し込み(Impression)クリープ試験(8)に括いて，動的再結晶が発現したとの 記述もあるが，動的再結晶が起こらない条件を選択して主に 実験を行って和り，動的再結晶についての調查は不十分であ

†芝浦工業大学大学院生, 現在 : ホンダェンジニアリング侏) (Graduate Student, Shibaura Institute of Technology, Present address: Honda Engineering Co., Ltd.)

\section{ると言える。}

動的回復によって転位密度を下げきれない場合, 動的再結 晶が発現すると考えられる。クリ一プ中の動的再結晶は 金 $^{(9)},=ッ ケ$ (10), 鉛(11), 白金 $^{(12)}$, 高純度アルミニウ ム(13)等で報告されている。このときにはクリープ速度が急 激に増加する現象 (strain burst, 後述)が観察される。高た 高歪に扎いても結晶粒は引き延ばされることなく，比較的等 軸な結晶粒からなる組織が観察される。

そこで, 本研究では, 高純度スズの圧縮クリープ試験およ び定速压縮試験を行い, 動的復旧過程に関する調查を行っ た、その結果, 動的再結晶の発現を示唆する strain burst が 観察された. 本稿では，この strain burstが動的再結晶によ るものかを解明し，動的復旧過程を明らかにする。

\section{II. 実 験 方 法}

\section{1. 多結晶供試材}

多結晶試験片の供試材として，99.998 mass\%スズ丸棒押 乙出し材 (Good Fellow 社製)を用いた。不純物濃度は，Fe: 
2, $\mathrm{Cu}: 7, \mathrm{~Pb}: 7, \mathrm{Ag}: 2, \mathrm{Ca}<1, \mathrm{Nb}<1$, 各 mass ppm である.

\section{2. 単結晶供試材}

単結晶試験片は改良 Bridgman 法で作成した。原料として 99.999 mass\%スズ(三菱マテリアル製)を用いた。主な不純 物濃度は, Fe: 3.0, Al: 2.6, Mg: 2.1, Ca: 1.0, Cu: 0.1, Pb: 1.0 各 mass ppm である.

これから単結晶を作成した。まず，鋳型(石英ガラス製)下 部に種結晶をはめ込み，鋳型上部に原料をセットした，装置 内部を真空にし，種結晶に冷やし金を当てながら，発熱体を 鋳型付近に近つけ種結晶を $5 \mathrm{~mm}$ 程, 材料と共に溶解した. 温度 $623 \mathrm{~K}$ で $7.2 \mathrm{ks}$ 保持を行った後, $5 \times 10^{-4} \mathrm{~mm} \cdot \mathrm{s}^{-1}$ の 速度で発熱体を引き上げた。できた単結晶を真空中，温度 $353 \mathrm{~K}, 21.6 \mathrm{ks}$ の焼鏠を行い，インゴット中の転位密度を均 一にした。作成した単結晶はサブバウンダリーを含まなかっ たＸ線により測定した長手方向の目的方位からのずれは， 最大 $0.026 \mathrm{rad}$ であった。

\section{3. 多結晶試験片}

供試材をダイヤモンドモンドカッターで切断した。切断に よって容易に再結晶が起こる，再結晶粒を削り落とす目的て 流水中でェメリ一研摩（５00～\#2400）を行ったささらに， 平行研摩治具を用いて $6 \mathrm{~mm} \times 6 \mathrm{~mm} \times 9 \mathrm{~mm}$ にした。

表面加工層を除去する目的で化学研摩(14)安行った。化学 研摩液には以下の 3 種類を用いた。研摩液 A : 60 mass\%硝 酸 4 容， 35 mass\%塩酸 1 容， 99 mass\%酢酸 1 容，純水 4 容。研摩液 B : 60 mass\%硝酸 1 容， 99 mass\%眽酸 1 容， 純水 1 容. 研摩液 C : 60 mass\%硝酸 1 容，99 mass\%酢酸 1 容, グリセリン 4 容.

化学研摩の手順は以下の通りである。まず，研摩液 A で 表面酸化皮膜を溶解した。これを水洗し，研摩液 B で研摩 を行った．表面の光沢がでる李で研摩を行った．再び水洗を 行い，研摩液 Cで研摩を行った．以上の操作によって表面 は鏡面となった。

内部歪を除去する目的で，焼鈍を行った。大気中，温度 $473 \mathrm{~K}$ ，時間 $3.6 \mathrm{ks}$ である。焼鈍後，再度化学研摩を行い， 表面を鏡面にした。試験片の平均結晶粒径は $1.48 \mathrm{~mm}$ と粗 大であった。

\section{4. 単結晶試験片}

圧縮軸が[110]になるよらにダイヤモンドカッターで切断 した。妡断部付近は多結晶化が起こるので，放電加工によっ てこの部分を除去した。この操作により， $5 \mathrm{~mm} \times 5 \mathrm{~mm}$ $\times 7.5 \mathrm{~mm}$ の角柱状とした。

多結晶と同様な条件で, 表面加工層除去の化学研摩, 歪取 り焼鈍，最終化学研摩を行った。これを微分干渉影微鏡で観 察し，試験片表面に結晶粒の生成していないものを試験片と した.

完成した試験片の転位密度をエッチヒロック法によって測
定した，転位密度は $3.36 \times 10^{9} \mathrm{~m}^{-2}$ であった，十分な焼鈍後 の金属の転位密度は $10^{10} \sim 10^{12} \mathrm{~m}^{-2(15)}$ なので，歪取り焼鈍 は十分に行われたことが分かる。

\section{5. クリープ試験}

圧縮クリープ試験にはレバー式定荷重クリープ試験機を用 いた。レバー比が 2:1である.大気中， $393 \mathrm{~K}$, 応力 3 $\mathrm{MPa} \sim 5.5 \mathrm{MPa}$ の範网で行った。温度保持精度は土1 Kで あった．压縮プラテンとして TiCセラミックス平行板を用 いた，潤滑剤として液体状グラファイトを塗布した，本条件 では良好な潤滑を示し，バレリングは回避された。

strain burst 前後の解析のため, 歪和よび応力を真歪, 真 応力に変換した。これはチャートから数値を読み, 次式によ って計算した。

$$
\begin{aligned}
& \varepsilon=-\ln \left(1-\varepsilon_{\mathrm{n}}\right) \\
& \sigma=\sigma_{\mathrm{n}}\left(1-\sigma_{\mathrm{n}}\right)
\end{aligned}
$$

ここで, $\sigma$ は真歪, $\varepsilon_{\mathrm{n}}$ は公称歪, $\sigma$ は真応力， $\varepsilon_{\mathrm{n}}$ は公称応 力である。

\section{6. 圧縮試験}

動的再結晶が発現すれば，応力-需曲線には応力振動が得 られるはずである。そこでインストロン万能試験機を用い て，温度 $393 \pm 1 \mathrm{~K}$ ，初期昰速度 $1.67 \times 10^{-4} \mathrm{~s}^{-1}$ で圧縮試験 を行った

\section{7. 組織観察}

自動研摩機の台座(後の化学研摩に耐えられるのでテフロ ンで作成)に試験片を固定した。これを研摩機にセットし， エメリ一研摩（\#500〜 \#2400）を観察面まで行った。試験片 が変形しないように最小荷重 $(1 \mathrm{~N})$ で研摩した。99.999 mass\% $\mathrm{Sn}$ 単結晶の常温付近での臨界分解㮍断応力は約 0.2 $\mathrm{MPa}$ である(16)のに対し，このとき試験片にかかる応力は概 算で最大 $0.128 \mathrm{MPa}$ 程度であり, 研摩中炕変形はしない.

エメり一研摩後, 即座に化学研摩(研摩液 A, B, C) 施 し，表面加工層を除去し平滑にした，同じ単結晶試験片の研 摩前，機械研摩化学研摩後について転位密度を比較した。両 者に大差はなく，サブバゥンダリーは形成されていなかった ため研摩による影響はないものと考学られた，微分干涉顕微 鏡叔よび偏光顕微鏡で組織観察を行った．化学研摩では粒界 やサブバウンダリーが優先的に腐食された。

格子の昰，サブグレインの形成などを検出し，結晶粒の力 位を見るために背面反射 X線写真を撮影した。タングステ ン製の対陰極を備えたX 線発生装置を用いた。撮影条件は

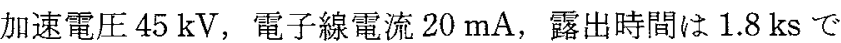
㐫った。 


\section{III. 結果および考察}

\section{1. 多結晶試験片におけるクリープ曲線}

Fig. 1 K応力3〜5.5 MPa に和忷るクリープ曲線を示す.

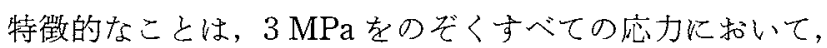
曲線の傾さが途中で大さく階段状に変化する。 3,4 打よび 5 $\mathrm{MPa}$ のクリープ速度の変遷を Fig. 2 亿示す. Fig. 1 火和け る $4 \mathrm{MPa}$ 拉よび $5 \mathrm{MPa}$ の階段状の大きな変化はクリープ速 度が急激に突出することに対応する。このような現象は strain burst と名付けられている. strain burstはクリープ速 度の減少中，つ毛加工硬化段階で起きている． $3 \mathrm{MPa} の$ 場合，3〜4ks 付近にやや山が見られるるのの，クリープ速 度は緩やかに減少し明膫な strain burstは見られない，現時 点では, strain burst と認められる明瞭な歪速度の突出と, それ以外の歪速度の山(例光ば $3 \mathrm{MPa}$ の場合の $3 \sim 4 \mathrm{ks}$ 付近) の差については明らかでない。

\section{2. 多結晶試験片における組織観察}

strain burst の有無に関わらず，変形後の組織は粒界が波

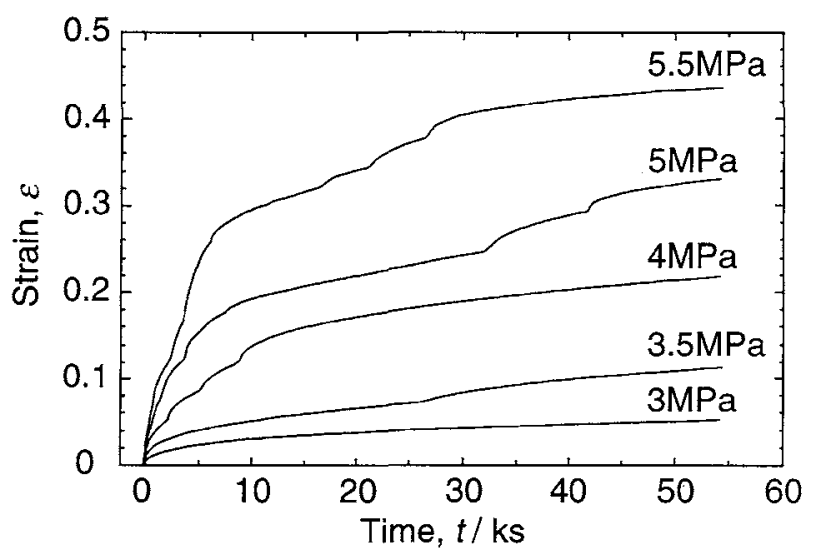

Fig. 1 Compressive creep curves of polycrystals at $393 \mathrm{~K}$.

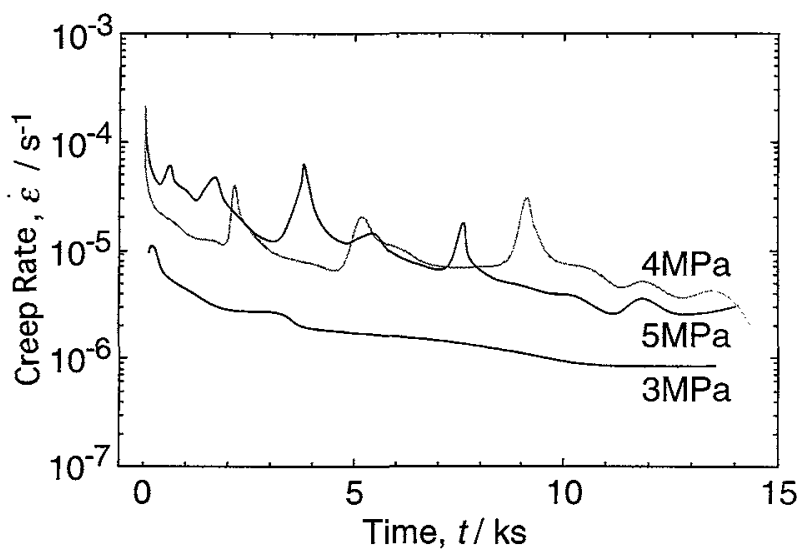

Fig. 2 Creep rate vs. time curves of polycrystals.
状化し，結晶粒はサブグレインを含んでいた，典型的な組織 をFig. 3 飞示す. $5 \mathrm{MPa}$ で歪0.33まで試験後の試料を偏光

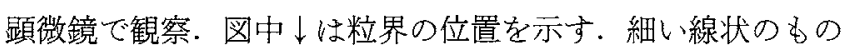
がサブバウンダリーである.サブバウンダリーとからんで, 粒界は曲がっている，写真でははっきりしないが，粒界とサ ブバウンダリーは偏光を強くかけることによって判別され る. 結晶方位の違いが色の濃淡差で観察されるためである。 結晶粒による色の濃淡は,アルミニウムで酸化膜を作った状 態(陽極酸化処理)でも観察(13)された。酸化膜を形成しやす いスズでも同じ理由で色の濃淡が観察されたことが考えられ

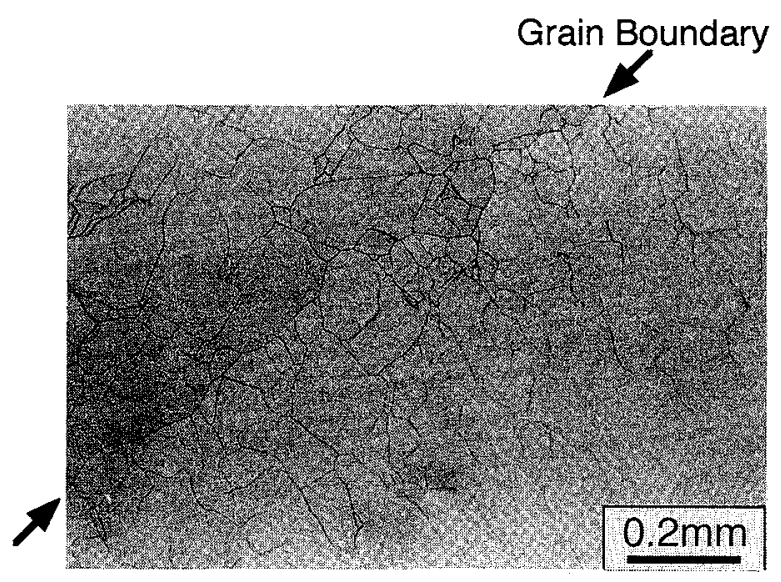

Fig. 3 Grain boundaries (indicated by arrows) and subboundaries of the polycrystals crept up to a strain of 0.33 at $5 \mathrm{MPa}$.
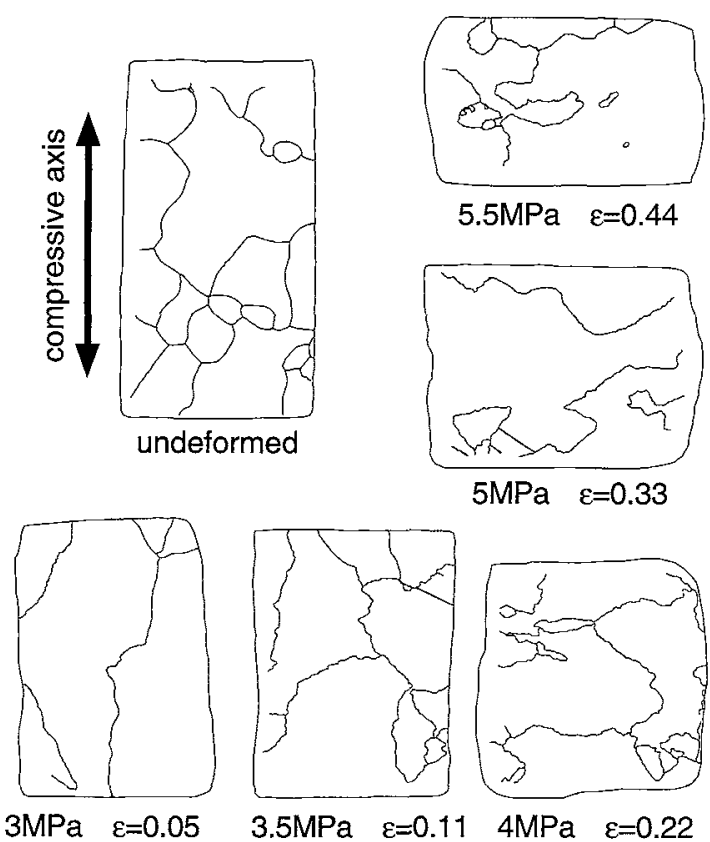

$2 \mathrm{~mm}$

Fig. 4 Grain boundary morphology of polycrystals crept for $54 \mathrm{ks}$. The corresponding strain is indicated below each figure. Typical grain boundary morphology of the undeformed specimen is shown in the upper left corner. 
3.

$54 \mathrm{ks}$ 試験後の試料全体の粒界をトレースしたすのを Fig. 4 に示す，比較のため，変形前の試験片についても示してい る(圧縮軸は紙面上下方向)。試験前の粒界はなめらかで, 粒 内にサブグレインは観察されない、变形後はいずれの試験片 に执いても粒界が波状化し，著しい粒成長が観察される。明 瞭な strain burst は起さない $3 \mathrm{MPa}$ が一番粒成長が著しい ことから，粒成長と strain burstは必ずしも関係ないものと 思われる。李た，3.5 MPa 执よび $5 \mathrm{MPa}$ に拈いては双晶粒 界らしいもの(図中の直線的精界， $5 \mathrm{MPa}$ では左下，3.5 $\mathrm{MPa}$ では右上)が観察された。これが，変形中に形成された ものか，変形前から存在していたかは不明である。変形双晶 であるならば，これに伴いstrain burstのよらな現象が起こ った可能性もある.

\section{3. 多結晶試験片の高温圧縮試験}

strain burst が動的再結晶によるならば，応力-歪曲線には 応力振動が現れることが予想される。そこで高温圧縮試験を 初期歪速度 $1.67 \times 10^{-4} \mathrm{~s}^{-1} て ゙$ 行った。得られた応力歪曲線 をFig. 5 に示す.ピーク応力を示した後, 加工硬化, 軟化 の過程を繰り返す多重応力振動を示し, 動的再結晶の発現を 強く示唆している.

\section{4. 単結晶試験片のクリープ曲線}

変形双晶は結晶格子の $c$ 軸力向, つをり $[001]$ 万向に応力 をかけたとき(1)に起こる。そこで, 変形双晶の出現を避ける ために[110]方位を圧縮軸とした。この方位付近では，衝撃 的な変形火よっても変形双晶は起こらず，変形様式はすべり によることが報告(18)されている。試験条件は多結晶におい て strain burst が顕著であった応力 $5 \mathrm{MPa}$ を選んだ。クり 一プ曲線(a)とクリープ速度の変遷(b)をFig. 6 亿示す。 こ こでは大きいstrain burstが $17 \mathrm{ks}$ 付近に観察される. Fig. 1 の $5 \mathrm{MPa}$ の多結晶に比べ出現は遅い. strain burst 直前の

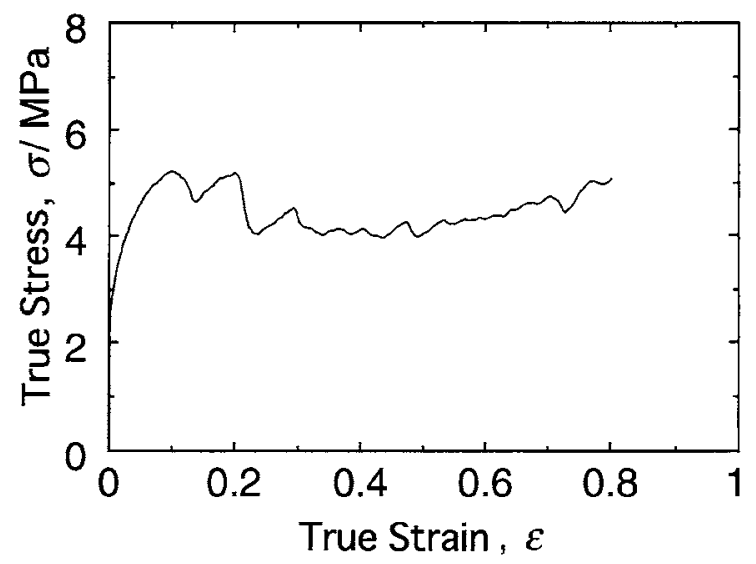

Fig. 5 True stress vs. true strain curve of polycrystals at a strain rate of $1.67 \times 10^{-4} \mathrm{~s}^{-1}$.
クリープ速度 $6.46 \times 10^{-6} \mathrm{~s}^{-1}$ に対し, strain burst 後のクリ ープ速度は $4.09 \times 10^{-4} \mathrm{~s}^{-1}$ と，その変化は約65倍であった。 多結晶のクリープ速度の変化が 4 倍程度であるのに比べ非 常に大きい。を， strain burst 発現は多結晶の場合より遅 かった。

\section{5. 単結晶試験片の組織観察}

strain burst 後の昰0.29に㧊ける変形組織を Fig. 7 に示 す.試験片全体の粒界をトレースしたものと，その一部 (Fig. 7 上白抜き部分)を微分干渉顕微鏡で観察したすのであ る. 圧縮軸に垂直な横断面で観察した。試験前には単結晶で あったが，試験後には三つの結晶粒となっている、粒界は波 状化しサブグレインを結晶粒内部に含至ことが分かる。

Fig. 7 の各結晶粒に X 線 (直径 $1 \mathrm{~mm}$ )を照射し, それらの ラウ工回折像を得た。これを Fig. 8 に示す. 各結晶粒のス ポットは引き延ばされ，それらはさらに細かく細分化されて いる.これは，変形を受けサブグレインを形成したことを示 す.この回折像はサブグレインが観察された組織観察と一致 する.ちなみに, 静的再結晶組織のものは, 明確なスポット を示した。それれぞれの結晶粒を比較すると，明らかに異なっ た方位を示し，[110]スポットをも明らかに異なっている。 単結晶であったものが，変形を受けた結晶粒から構成される
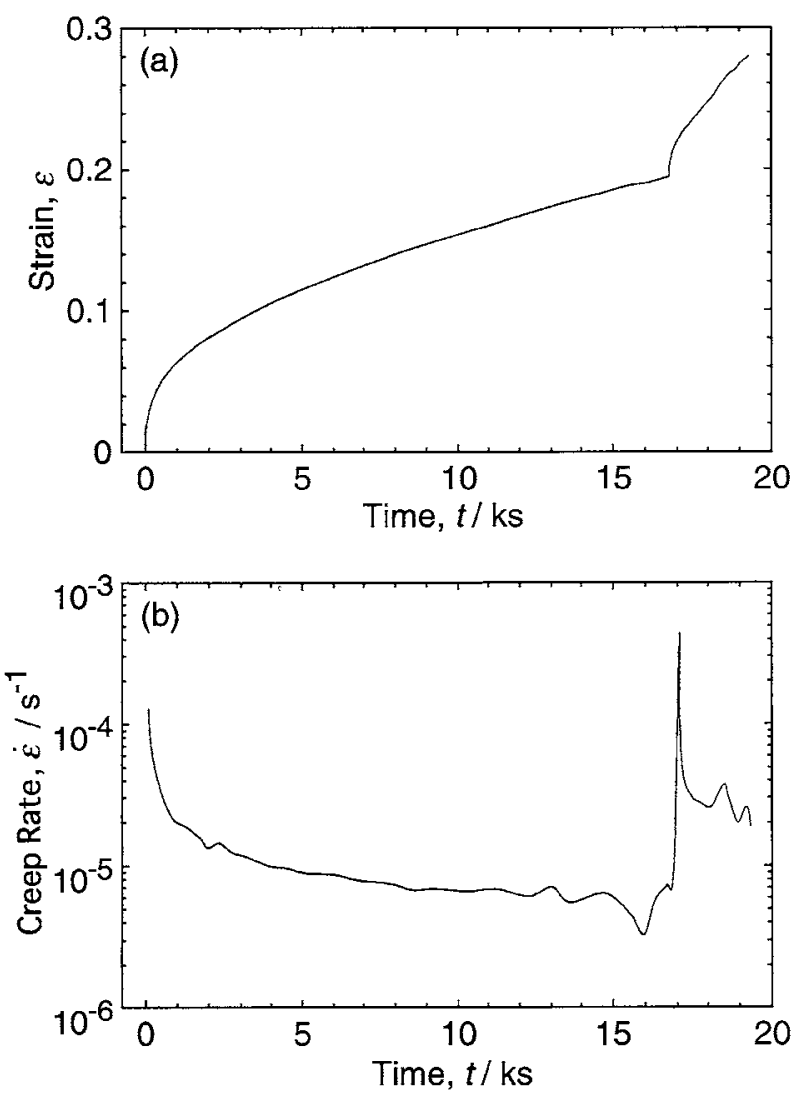

Fig. 6 Creep curve (a) and creep rate vs. time curve (b) of a [011] single crystal at $5 \mathrm{MPa}$. 


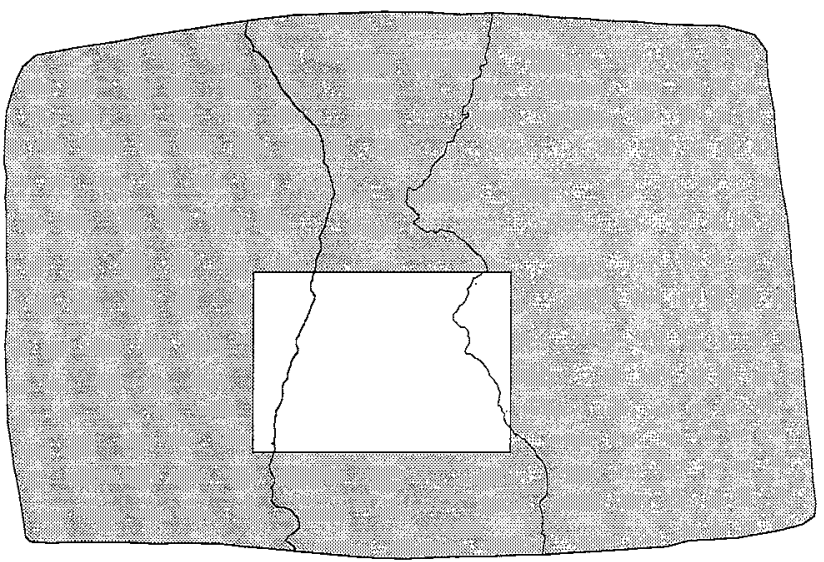

\section{$2 \mathrm{~mm}$}

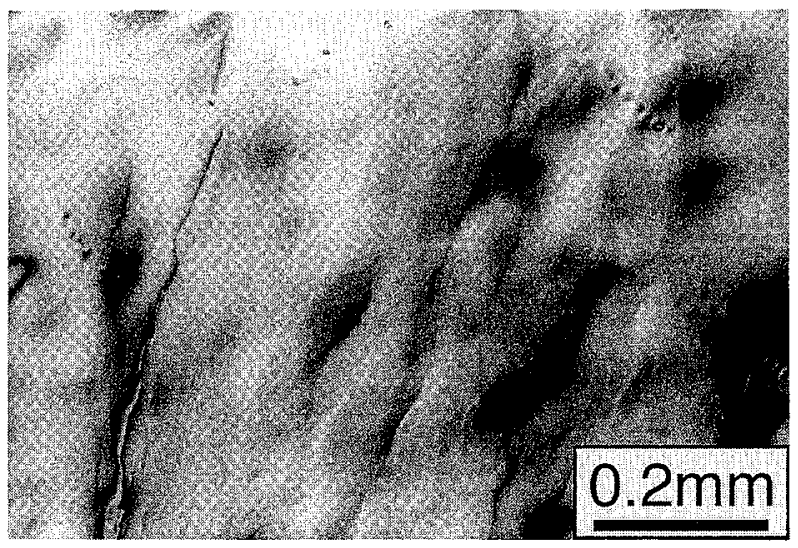

Fig. 7 Dynamically recrystallized grains (upper drawing) and subgrains in the grains (lower micrograph) observed after the creep test up to a strain of 0.29 at $5 \mathrm{MPa}$.
組織となるには，核の生成一成長を経る動的再結晶が起きた ことでしか説明できない。

\section{6. strain burst と動的再結晶の関係}

クリープ中の動的再結晶に関する報告は他金属では多 数(9)-(13) あり, strain burst の発現が観察されている。本実 験の strain burst の原因は変形双晶ではなく, 動的再結晶に 起因することは明らかである。しかしながら，多結晶の場合 には, strain burstの原因として他の可能性も考光られる.

Straubと Blum ${ }^{(19)}$ はアルミニウム多結晶 (99.99 mass\% $\mathrm{Al}$, 粒径 $3.5 \mathrm{~mm}$ )の高温圧縮クリープ試験に打いて突発的 にクリープ速度が増大する現象を報告している。粒内にはサ ブグレインを含む組織とともに長距離の粒界移動が見られた ことから，クリープ速度の增加は粒成長によるものと結論づ けた。これをMcQueen $5^{(20)}$ は, 動的結晶粒成長 (dynamic grain growth) と称し，山縣の報告(21)した高純度アルミニウ ム多結晶の高温圧縮試験の応力振動を, これによるものと指 摘した．本実験でも同様なことが考学られなくもないが，粒 成長は strain burst の有無に関わらず発現していること，末 た，単結晶で strain burst が出ることは明らかなので，多結 晶の場合も strain burst の原因性動的再結晶であると考学る のが自然である．粒界移動することによって雪エネルギを低 下させることが知られている。これを歪誘起粒界移動(バル ジング機構) (22)(23)といらが, 本実験の粒成長はこれに相当 すると考えられる。

サブグレインが生成し，粒界が凹凸化したところに動的再 結晶核の出ることが多く報告されている.これは凹凸化した 粒界で粒界すべりが起き，不均一変形が導入されることによ る(23)。粒界すべりが起こっているか確認するために多結晶 試料の表面を平滑にし，応力 $5 \mathrm{MPa}$ で strain burst 直前の 雨 0.05 までクリープ試験を行った。そと表面の SEM 写真を
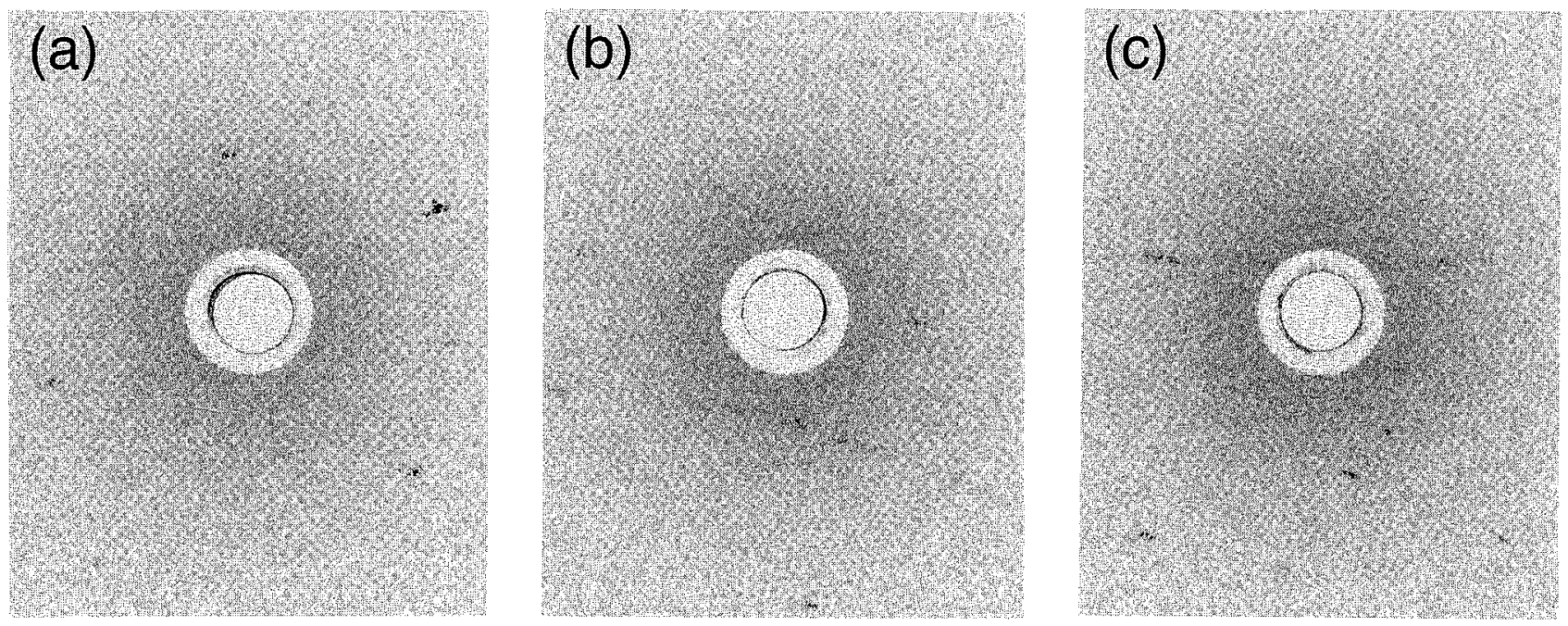

Fig. 8 Laue back reflection photographs for the dynamically recrystallized crystals. (a) pattern obtained from the left grain, (b) from the central grain, and (c) from the right grain in Fig. 7. 
Fig. 9 亿示寸（a）から，粒界移動によって粒界が波状化し

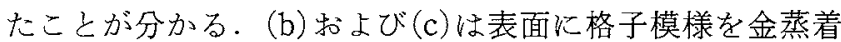
して試験したものである。（b）から粒界移動で粒界は波状化 するが，格子模様に変化が見られない，粒界移動で波状化す るときには粒界すべりのよらな不均一歪は導入されないこと が分かる. (c)では粒界を挟んで格子模様がずれている箇所
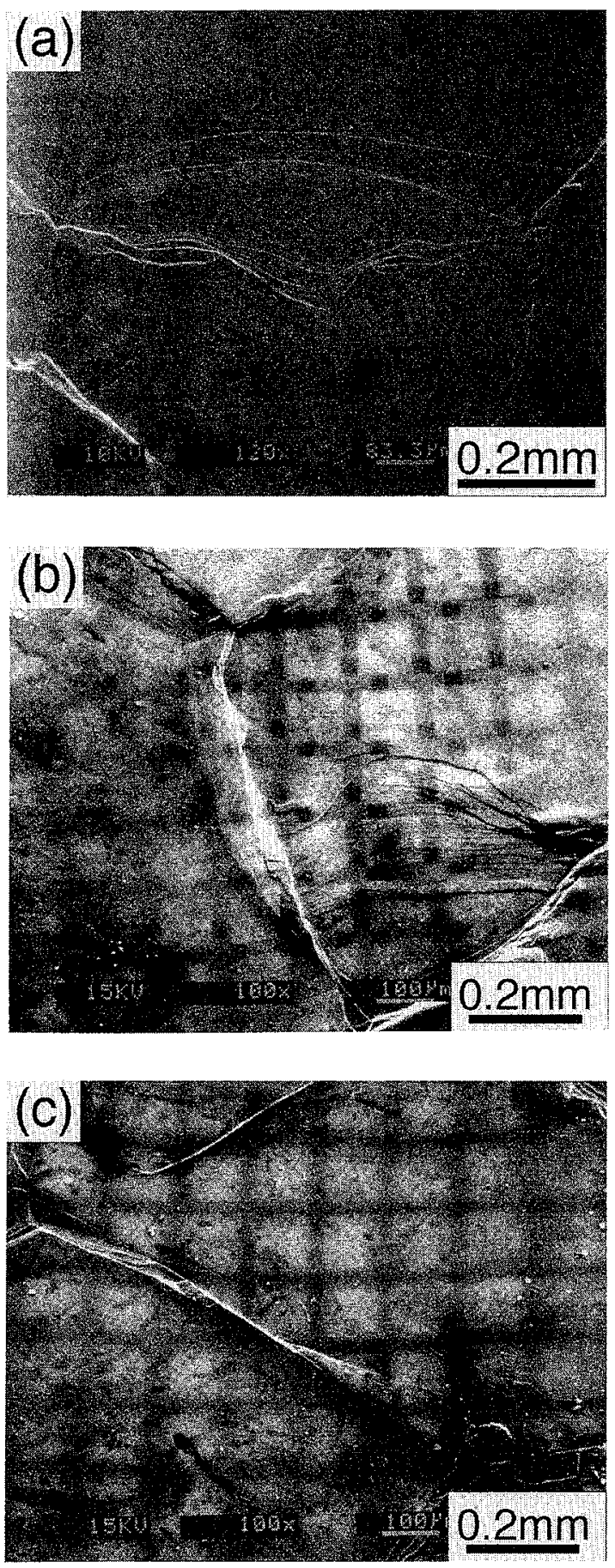

Fig. 9 Scanning electron micrographs of polycrystalline specimens crept up to a strain of 0.05 at $5 \mathrm{MPa}$. Grain boundary migration in (a) and (b), and grain boundary sliding in (c).
が観察され，粒界すべりが起こっている。このとき，粒界は 波状化していない，この上うな箇所の方が不均一変形が導入 され核生成サイトとなり得るであるら，粒界が激しく波状化 しているところが必ずしも核生成サイトと成り得るわけでは ないとい党る. strain burst 発現までの時間, 歪が単結晶上 り多結晶の方が少ないのは, 多結晶の粒界すべりが動的再結 晶の発現を促進しているためとる考光られる.

\section{7. strain burst 前後でのクリープ速度変化}

多結晶と単結晶の strain burst 時のクリープ速度の変化は そ机朰れ 4 倍，65倍と，実に10倍以上も異なる。この原因 を以前, 高純度アルミの strain burst の解析で用いた方 法(17) 基づき考察する。

strain burst は軟らかい新粒(動的再結晶粒)の急激な生成 を伴って起こる現象と考兄られる. 变形の進行に伴い加工硬 化した結晶中に, 新粒が発生し, 発生した新粒がある程度大 きくなった状態を考光る。この状態で，新粒の体積率 $V_{\mathrm{DR}}$, 变形応力 $\sigma_{\mathrm{DR}}$, 加工硬化粒の体積率 $V_{\mathrm{WH}}$, 变形応力 $\sigma_{\mathrm{WH}}$ ह

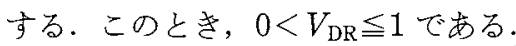

まず，strain burstが新粒生成に伴って生じるとすると， strain burst 前後の変形速度比 $\dot{\varepsilon}_{S \mathrm{~B}} / \dot{\varepsilon}$ は, 次式(17)で与兄られ る.

$$
\dot{\varepsilon}_{\mathrm{SB}} / \dot{\varepsilon}=1 /\left[1-(1-1 / k) V_{\mathrm{DR}}\right]^{n}
$$

\section{ここで, $n$ 蛙応力指数, $k=\sigma_{\mathrm{WH}} / \sigma_{\mathrm{DR}}$}

式より, 縦軸飞変形速度比, 横軸飞体積比としてプロット したすのをFig. 10 亿示す、スズのクリープに括いて応力指

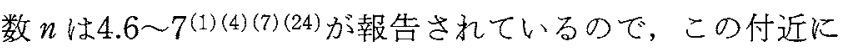

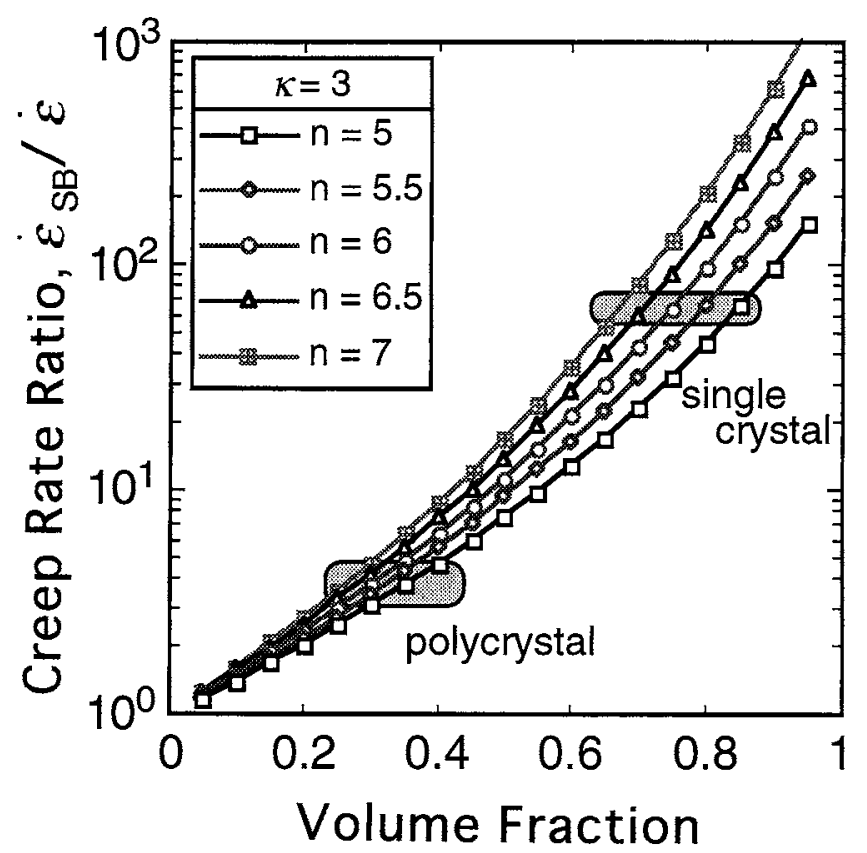

Fig. 10 Calculated creep rate ratio vs. volume fraction of new grains. The two indicated portions correspond to the experimentally observed values for a single crystal and polycrystals. 
ついて示した． $k$ の值は 3 を用いた．圧縮試験の応力振動 (Fig. 5) も動的再結晶によるものと考えられる.この時, 降 伏応力 $(1.62 \mathrm{MPa})$ が新粒の変形応力 $\sigma_{\mathrm{DR}}$, ピーク応力 $(5.17$ $\mathrm{MPa})$ が加工硬化粒の変形応力 $\sigma_{\mathrm{WH}}$ に相当すると仮定する と，その比率が 3 程度であったためである.

図より体積率が高くなる汪ど，つまり動的再結晶粒が大き く成長するほど， strain burstによるクリープ速度比が大き い．本試験のクリープ速度比は多結晶が 4 倍，単結晶が65 倍ということを考えると，多結晶試験片では新粒が大きくは 成長できず，多結晶と単結晶の違いなので既存の粒界が粒成 長を妨げていることが想像できる．多結晶の動的再結晶過程 で粗粒化する場合，粒界上で生ずる新粒が結晶粒同士の衝突 を起こし，準安定な粒径を生ずる(25)ことが知られている. すでにある粒界が新粒成長の抵抗となり粒成長は止まるか減 少するといらことである．多結晶の場合には既存の結晶粒が strain burst 時に成長できる最大の体積率と考えられる。 strain burst 前に粒成長する事や試験後の試験片には特に粗 大な結晶粒が 2,3 個が存在する.この粗大結晶粒が試験片 の体積の 3 4 割程度 (粗大粒すぎて通常の粒径測定法を用 いることがでさないので括拈よその值)を占めた(Fig. 10 の 横軸 $0.3 \sim 0.4)$ とするとクリープ速度の変化は計算值と良く 一致する。一方，単結晶の場合には旧粒界が存在しない、新 粒の粒界が高速で移動し, 試験片の大部分である 7〜9 割程 度を新粒が占めたと考えると，クリープ速度変化の值は計算 值と良く一致する。

粗大粒であったことが strain burst の観察された理由と思 われる。明確に strain burst を検出するにはクリープ速度比 を大きくするといらことなので，粗大結晶粒であった方が望 ましい，一般的には微細粒の方が動的再結晶が起こりやすい 事が知られているが，スズの微細粒では先の理由から動的再 結晶の発現は変形挙動(strain burst)に現れにくいと考兄ら れる. 高純度アルミニウムの場合も粗大結晶粒の方が現れや すい(26). 今までスズのクリープ試験で strain burst の報告 がないのはこのような理由からかもしれない.

\section{N. 結 言}

純スズの圧縮クリープ試験, 定速圧縮試験を $393 \mathrm{~K}$ で行 った。その結果次のようなことが明らかになった

(1) 多結晶, 単結晶ともにクリープ速度の急激な増加であ
る strain burst が観察される.これは動的再結晶の発現に起 因する。

（2）定速圧縮試験に执いて $[110]$ 単結晶は，動的再結晶に 典型的な多重の応力振動を示す。

（3） strain burstに伴らクリープ速度の増加は，多結晶は 4 倍程度, 単結晶は65倍程度である. 多結晶の場合には既存 粒界が新粒の成長を妨げるためクリープ速度の増加は少ない と考光られる，そして新粒が大きく成長するほど大きくなる と言える。

(4) 多結晶の strain burst は単結晶よりも早期に出現す る。多結晶では粒界すべりによる不均一変形が導入され，新 粒の核生成場所として働くためと考兄れる。

\section{文献}

(1) J. Weertman and J. E. Breen: J. Appl. Phys., 27 (1956), 1189.

(2) O. D. Sherby and J. Weertman: Acta Metall., 27 (1979), 387.

( 3 ) R. E. Frenkel, O. D. Sherby and J. E. Dorn: Acta Metall., 3 (1955), 470.

(4) J. E. Breen and J. Weertman: J. Metals, 7(1955), 1230

(5) J. Weertman: J. Appl. Phys., 28 (1957), 196.

(6) S. H. Shu, J. B. Cohen and J. Weertman: Metall. Trans. A, 14 (1983), 117.

(7) P. Adeva, G. Caruana, O. A. Ruano and M. Torralba: Mater. Sci. Eng. A, 194(1995), 17.

(8) S. N. G. Chu and J. C. M. Li: Mater. Sci. Eng., 39(1979), 1.

(9) D. Hardwick, C. M. Sellars and W. J. McG Tegart: J. Inst. Metals, 90(1961-62), 21.

(10) R. C. Gifkins: J. Inst. Metals, 87 (1958-1959), 255.

(11) G. J. Richardson, C. M. Sellers and W. J. McG. Tegart: Acta Metall., 14(1966), 1225.

(12) T. Hamada, S. Hitomi and Y. Ikematsu: Mater. Trans., JIM, 37 (1996), 353

(13）山縣 裕, 大塚正久：まてりあ, 36(1997), 795.

（14）藤原雅美，広川友雄：日本金属学会誌，51(1987), 830.

（15）杉本孝一, 長村光造, 山根寿己, 牧正志, 菊池潮美, 落合 庄治郎, 村上陽太郎: 材料組織学, 朝倉書店, (1995), 142.

(16) N. Nagasaka: J. J. Appl. Phys., 28(1989), 446.

（17）小池俊之, 田中康介, 山縣 裕, 大塚正久：日本金属学会誌, 62(1998), 44.

(18) T. Hirokawa: J. Sci. Hiroshima Uni., 23A(1960), 637.

(19) S. Straub and W. Blum: Scripta Met. Mater., 24(1990), 1837.

(20) H. J. McQueen, W. Blum, S. Staurb and M. E. Kassner: Scripta Met. Mater., 28(1993), 1299.

(21) H. Yamagata: Scripta Met. Mater., 27(1992), 201.

(22) 牧 正志, 田村今男 : 鉄と鋼, $\mathbf{1 5}(1984), 2073$.

(23) 酒井 拓: 鉄と鋼, 81(1995), 1.

(24) F. A. Mohamed, K. L. Murty and J. W. Morris, JR.: Metal. Trans., 4(1972), 935.

（25）酒井 拓：日本金属学会会報, 22(1983), 1036

(26) 藤田将巨, 大塚正久, 山縣 裕, 小池俊之, 田中康介：第93 回秋期軽金属学会概要集，(1997), 325. 